EWA KARMOLIŃSKA-JAGODZIK

ORCID 0000-0001-6076-8087

Uniwersytet im. Adama Mickiewicza

$w$ Poznaniu

\title{
ZABURZENIA DEPRESYJNE WŚRÓD STUDENTEK I STUDENTÓW W POLSCE ${ }^{1}$
}

\begin{abstract}
AвSTRACt. Karmolińska-Jogodzik Ewa, Zaburzenia depresyjne wśród studentek i studentów w Polsce [Depressive Disorders Among Students in Poland]. Studia Edukacyjne nr 55, 2019, Poznań 2019, pp.139162. Adam Mickiewicz University Press. ISSN 1233-6688. DOI: $10.14746 /$ se.2019.55.9

This article describes depressive disorders among contemporary students in Poland. The research results analyses data obtained in the national survey in 2019 on a group of 4,500 full-time and extramural students ${ }^{2}$. The selection of the research sample was consistent with a random selection. The research was carried out in a research team (Prof. dr hab. A. Cybal - Michalska, Prof. UAM, dr hab. S. Jaskulska, Prof. UAM, dr hab. N. Walter, Dr. M. Marciniak, Dr. E. Karmolińska - Jagodzik) under the guidance of prof. UAM, dr hab. Jacek Pyżalski under the grant implemented for the State Agency for Solving Alcohol Problems. Issues related to depression were within the scope of my analysis. This article includes a description of the causes of depression and the theoretical disorder itself. In addition, it article provides an analysis of the test results using the Beck test in individual subscales for students in Poland. The article is a diagnostic approach to the student community in Poland in the scope of the phenomenon discussed.
\end{abstract}

Key words: depressive disorder, students, Beck's test

\section{Wstęp}

Rozpoczynając rozważania na temat zaburzeń nastroju, których dotyczy depresja, warto wskazać, czym jest zdrowie psychiczne, aby mieć rozezna-

${ }^{1}$ Publikacja powstała w rezultacie badań „Studenci 2019”, realizowanych przez UAM w ramach konkursu Państwowej Agencji Rozwiązywania Problemów Alkoholowych na realizację zadań z zakresu zdrowia publicznego, określonych w Narodowym Programie Zdrowia na lata 2016-2020 w obszarze celu operacyjnego $\mathrm{nr}$ 2. Profilaktyka i rozwiązywanie problemów związanych z używaniem substancji psychoaktywnych, uzależnieniami behawioralnymi i innymi zachowaniami ryzykownymi: zadanie 40/3.4.2/19/DEA - Wspieranie badań naukowych w obszarze czynników ryzyka i czynników chroniących przed problemami wynikającymi z picia alkoholu.

${ }^{2}$ Interestingly, the largest study group in Poland so far with the BDI questionnaire was 3,339, in the Czapiński survey (1993) between 1991 and 1992. Our study covers 4,500 subjects. 
nie odnośnie granic zachowań natury ludzkiej. Zdrowie psychiczne, zgodnie z przyjętą w 1948 roku Konstytucją Światowej Organizacji Zdrowia, to nic innego, jak „pełny dobrostan fizyczny, psychiczny i społeczny człowieka” ${ }^{3}$. Jednakże, na przestrzeni lat powstało wiele definicji zdrowia psychicznego, które wynikają z uwarunkowań kulturowych, subiektywnych odczuć, bądź przeciwstawnych teorii naukowych. To, co łączy większość teorii, stanowi pojmowanie zdrowia psychicznego i zaburzeń psychicznych jako przeciwstawnych wobec siebie, czyli brak rozpoznanej choroby psychicznej nie musi oznaczać zdrowia psychicznego. Według K. Dąbrowskiego, zdrowie psychiczne to:

zdolność do rozwoju w kierunku wszechstronnego rozumienia, przeżywania, odkrywania i włączenia się w coraz wyższą hierarchię rzeczywistości i wartości, aż do ideału indywidualnego i społecznego ${ }^{4}$.

Na przestrzeni lat zjawisko depresji wyjaśniano w przeróżny sposób, a pokłosie rozlicznych teorii $\mathrm{w}$ przestrzeni potocznej funkcjonuje do dzisiaj. Pomimo tak odległego zainteresowania tym zjawiskiem, a zaburzeniami i chorobami psychicznymi w ogóle, brakowało ujednoliconego systemu klasyfikacji, co powodowało zróżnicowane diagnozy stawiane przez specjalistów czy zespoły badawcze. Taki stan rzeczy doprowadził do ujednolicenia zaburzeń i chorób, który skutkował powstaniem powszechnie obowiązującej klasyfikacji. Obecnie powszechnymi klasyfikacjami są: DSM - 5, która obowiązuje w USA, oraz ICD - 10 obowiązująca w Europie.

W badaniach epidemiologicznych szacuje się, że omawiane zaburzenie dotyczy do 15\% adolescentów i młodych dorosłych, dwukrotnie częściej młodzież żeńską niż męską. Pierwsze epizody depresji mają przeważnie miejsce w okresie adolescencji, pomiędzy 12. a 18. rokiem życia. Kolejny wzrost zachorowań następuje po 19. roku życia. Ocenia się, że szczególnie narażona na wystąpienie objawów depresji jest młodzież studencka ${ }^{5}$.

\section{Przyczyny depresji w ujęciu współczesnym}

Etiopatogeneza tego zaburzenia jest złożona ${ }^{6}$. Po wielu latach intensywnych prac nad jego przyczynami badacze największe znaczenie przypisują 2019].

${ }^{3}$ https://www.who.int/mental_health/management/depression/en/ [data dostępu:02.11.

${ }^{4}$ K. Dąbrowski, Zdrowie psychiczne, Warszawa 1985.

${ }^{5}$ E. Mojs i in., Wtaściwości psychometryczne polskiej wersji skróconej Skali Depresji Kutchera dla Młodzieży (Kutcher Adolescent Depression Scale) - pomiar depresji w grupie studentów, Psychiatria Polska, 2015, 49(1), s. 135-144.

${ }^{6}$ G. Hasler, Patofizjologia depresji: czy mamy jakieś solidne dowody naukowe interesujące dla klinicystów? Postępy Psychiatrii i Neurologii, 2011, 20, s. 5-22; K.E. Shannon i in., Familial and 
czterem czynnikom: stresującym wydarzeniom życiowym, wczesnodziecięcym stresującym wydarzeniom życiowym, roli osi podwzgórze-przysadkanadnercza (PPN) oraz predyspozycjom genetycznym ${ }^{7}$. Stresujące wydarzenia życiowe obejmują wydarzenia o charakterze utraty lub przeciążenia, takie jak zmiany statusu finansowego, konflikty interpersonalne, zawody emocjonalne, konflikty małżeńskie i rodzinne, choroby przewlekłe, czy śmierć osoby bliskiej. Istotną rolę w patogenezie depresji odgrywają również wczesne stresujące wydarzenia życiowe, takie jak wykorzystywanie seksualne, nadużywanie fizyczne, psychiczne, czy zaniedbania wychowawcze w dzieciństwie. Wskazując na deregulację osi PPN, należy zauważyć, że szczególne znaczenie w etiologii depresji mają badania neuroendokrynologiczne, które wskazały, że istotną rolę $\mathrm{w}$ mechanizmach reakcji stresowej odgrywa kortykoliberyna (CRF) oraz kortyzol ${ }^{8}$, które stanowią mechanizm pośredniczący pomiędzy stresującymi wydarzeniami życiowymi, zwiększoną podatnością na stres, a zmianami biologicznymi obserwowanymi w depresji. Coraz częściej spotkać można wyniki badań, które wyjaśniają depresje poprzez dziedziczenie podatności genetycznej, która warunkuje indywidualną odpowiedź na stres ${ }^{9}$.

Zgodnie z doniesieniami współczesnych badań ${ }^{10}$, depresja jest również związana z zaburzeniami w wydzielaniu neuroprzekaźników, które mają poważne konsekwencje dla całego organizmu. Niewłaściwe wydzielanie neuroprzekaźników negatywnie wpływa na funkcjonowanie układu nerwowego jako całości; dochodzi wówczas do patologii poszczególnych układów. U osób z depresją zaobserwowano obniżoną ilość GABA, serotoniny i noradrenaliny. Tak zmieniona ilość wystarczy, by zmienić człowieka w stu procentach niezależnie od tego, jakim usposobieniem cechował się w przeszłości.

tempera-mental predictors of resilience in children at risk for conduct disorder and depression, Development and Psychopathology, 2007, 19, s. 701-727; M. Mitjans, B. Arias, The genetics of depression: What information can new methodologic approaches provide? Actas Esp Psiquiatr, 2012, 40, s. 70-83; A. Rajewska-Rager, J. Rybakowski, Rola stresujacych wydarzeń życiowych w patogenezie depresji, Neuropsychiatria i Neuropsychologia, 2008, 3, s. 147-152.

7 E. Mojs i in., Wtaściwości psychometryczne polskiej wersji skróconej Skali Depresji Kutchera, s. 135-144; A. Rajewska-Rager, J. Rybakowski, Rola stresujacych wydarzeń życiowych w patogenezie depresji, s. 147-152; S. Godlewski, P. Czerski, Badania genetyczno-molekularne metoda analizy sprzeżeń dotyczace schizofrenii. Przegląd piśmiennictwa, Nowiny Lekarskie, 2000, 69, s. 705-718.

8 B. Jonata, M. Załuska, Poziom kortyzolu, dehydroepiandrosteronu i jego siarczanu (DHEA i DHEA-S) w surowicy krwi a obraz lipidogramu i reakcja na leczenie u kobiet $z$ depresja, Psychiatria Polska, 2011, XLV, 6, s. 861-873.

9 S. Godlewski, P. Czerski, Badania genetyczno-molekularne metoda analizy sprzężen dotyczace schizofrenii, s. 705-718; A. Szpera, Badania genów kandydujacych zwiazanych z układem serotoninergicznym $i$ dopaminergicznym w zespole obsesyjno-kompulsywnym, Nowiny Lekarskie, 2008, 77, s. 172-177.

10 A.E. Markowicz-Narękiewicz, Związek pomiędzy wydzielaniem neuroprzekaźników a powstaniem chorób psychicznych - na szczegótowo omawianym przykładzie depresji, [w:] Neurokognitywistyka w patologii i zdrowiu, Szczecin 2015, s. 55-59. 
Coraz rzadziej, ale jednak nadal funkcjonuje podział na depresję endogenną i egzogenną (reaktywną), o której wspominał Z. Freud. Depresja endogenna, często utożsamiana z dużą depresją, uwarunkowana jest biologicznie (m.in. genetycznie), charakteryzuje się brakiem uchwytnej przyczyny zewnętrznej (np. stresujących okoliczności lub przeżyć) oraz zwykle wysokim nasileniem dolegliwości. Natomiast, depresję egzogenną łączy się z czynnikami psychospołecznymi lub wcześniejszymi stresującymi, przytłaczającymi wydarzeniami, na przykład utratą bliskiej osoby, niepowodzeniami życiowymi lub innymi problemami zdrowotnymi.

Podział depresji na postać endogenną i egzogenną nie jest akceptowany przez wszystkich badaczy i klinicystów. Niektórzy przyjmują, że w rzeczywistości jest to ta sama depresja jednobiegunowa, a powyższy podział opiera się wyłącznie na nasileniu objawów ${ }^{11}$.

\section{Depresja w DSM - 5}

Jednym z najważniejszych pojęć dla opisania stanu depresji i zrozumienia jego etiologii jest pojęcie rozregulowania organizmu, zaburzenie homeostazy. Depresja nie może być rozumiana jako dłuższa, intensywniejsza albo szczególnie dotkliwa reakcja na jakieś bodźce. Mylące są też określenia depresji jako "obniżonego nastroju, z którym nie potrafimy sobie poradzić”. Różnica nie jest ilościowa, zmiany chorobowe dotyczą ponadto wielu funkcji organizmu ${ }^{12}$.

Opisując depresję, nie sposób zatem pominąć kwestii emocji i nastrojów. O tyle, o ile emocje są krótkotrwałe i łatwe do rozpoznania, a ich konsekwencje trwania $\mathrm{w}$ organizmie nie muszą być destrukcyjne, tak nastroje trwają zdecydowanie dłużej i ich zaburzenia mają swoje długoterminowe destrukcyjne konsekwencje. Emocja to nic innego niż stan znacznego pobudzenia organizmu. Emocje charakteryzują się tym, że pojawiają się nagle i zawsze łączą się z zaburzeniem somatycznym; mogą osiągnąć dużą intensywność, ale są przejściowe. We współczesnym znaczeniu tego słowa emocja implikuje aspekt działaniowy, reakcyjny i nie jest równoznaczna z pasywnym uczuciem $^{13}$. Jeżeli jednak stan emocjonalny utrzymuje się dłuższy czas i jednostka nie ma normatywnych metod poradzenia sobie z konsekwencjami pobudzenia układu limbicznego i doprowadzenia do wygasania reakcji emo-

${ }_{11}$ B.J. Sadock, V.A. Sadock, P. Ruiz, Kaplan \& Sadock's Synopsis of Psychiatry Behavioral Sciences/Clinical Psychiatry, Wyd. 11, Philadelphia 2015; Psychiatria, red. J. Rybakowski, J. Wciórka, tom II, Wrocław 2011, s. 343-415.

${ }_{12}$ B.R. Godlewska, Genetyka i psychiatria w praktyce lekarskiej, Psychiatria w Praktyce Ogólnolekarskiej, 2007, 7(2), s. 97-109.

${ }^{13}$ W. James, The principles of psychology, New York 1890. 
cjonalnych, wówczas emocja staje się długotrwała i oznacza, że przeradza się w nastrój, który trwa znacznie dłużej i rzutuje na dalszą perspektywę oceny rzeczywistości i to jak postrzegane jest życie, inne osoby oraz własna osoba.

Zaburzenie depresyjne należy do grupy zaburzeń związanych z epizodami nastroju lub zaburzeniami nastroju.

W DSM - 5 wykorzystano trzy grupy zestawów kryteriów do diagnozowania problemów psychicznych związanych z nastrojem: 1) epizody nastroju, 2) zaburzenia nastroju, 3) uszczegółowienia opisujące ostatni epizod i przebieg nawracania.

Na potrzeby niniejszego opracowania posłużymy się opisaniem epizodu nastroju i zaburzenia nastroju.

Rozpoznawanie zaburzonego nastroju jest bardzo ważne, gdyż aż 20\% dorosłych kobiet i 10\% dorosłych mężczyzn może doświadczyć w pewnym momencie swojego życia zaburzeń nastroju. Pojawiają się one u osób bez względu na pochodzenie, klasę społeczną, wykształcenie, zasoby materialne, czy kompetencje społeczne. Prawdopodobieństwo pojawienia się ich u osób, którzy mają krewnych z zaburzeniami nastroju jest większe niż u pozostałych ${ }^{14}$.

Epizody nastroju oznaczają każdy okres, kiedy pacjent czuje się nienormalnie szczęśliwy lub smutny. Epizody nastroju to elementy budulcowe, które składają się na wiele kodowanych zaburzeń. Większość pacjentów z zaburzeniami nastroju będzie doświadczać co najmniej jednego z trzech epizodów: depresyjnego, maniakalnego lub hipomaniakalnego ${ }^{15}$.

Epizod depresyjny to jeden z elementów budulcowych zaburzeń nastroju, ale nie jest to kodowana jednostka diagnostyczna. Przez co najmniej 2 tygodnie pacjent ma obniżony nastrój (lub nie potrafi cieszyć się z życia) oraz doświadcza problemów z jedzeniem i snem, poczucia winy, utraty energii, trudności z koncentracją i myśli o śmierci.

Epizod maniakalny. Przez co najmniej tydzień pacjent ma podwyższony nastrój i może przejawiać poczucie własnej wielkości, rozmowność i podatność na rozproszenie uwagi. Zła ocena sytuacji prowadzi do znacznego ograniczenia funkcjonowania społecznego lub zawodowego, często pacjenci muszą być hospitalizowani.

Epizod hipomaniakalny. Przypomina epizod maniakalny, ale jest krótszy i charakteryzuje się mniejszym nasileniem. Hospitalizacja nie jest wymagana.

Natomiast zaburzenia nastroju to wzorzec chorobowy spowodowany nieprawidłowym nastrojem. Prawie każdy pacjent, u którego pojawia się zaburzenie nastroju, doświadcza w jakimś czasie depresji. Wiele jednak zaburzeń nastroju rozpoznaje się na podstawie epizodu nastroju. Tak więc zaburzenia

\footnotetext{
${ }^{14}$ J. Morrison, DSM-5 bez tajemnic. Praktyczny przewodnik dla klinicystów, Kraków 2016.

15 Tamże.
} 
depresyjne (MDD - major depressive disorder), o których tutaj mowa to stan, w którym u pacjenta występuje co najmniej jeden epizod depresyjny i który nie ma objawów manii lub hipomanii. Depresja należy do grupy zaburzeń psychicznych odnoszących się do zespołu objawów występujących w przebiegu chorób afektywnych ${ }^{16}$.

O depresji mówimy wówczas, kiedy poniższe objawy występują niemal każdego dnia. Zatem, na obraz kliniczny depresji składa się występowanie, co najmniej przez 2 tygodnie 5 takich objawów, jak: obniżony nastrój, utrata przyjemności, utrata łaknienia i masy ciała, znużenie, zahamowanie psychoruchowe, niskie poczucie własnej wartości lub poczucie winy, problemy z koncentracją uwagi ${ }^{17}$. Pacjenci z depresją mogą mieć więcej objawów niż podane powyżej. Mogą mieć okresy płaczu, fobie, obsesje i kompulsje, mogą przyznawać się do poczucia beznadziejności, bezradności lub bezwartościowości.

\section{Test Becka - opis narzędzia badawczego}

Kwestionariusz do pomiaru nasilenia objawów zespołu depresyjnego został opracowany przez Aarona Becka i współpracowników w roku 1961. Treść testu dotyczy najczęściej opisywanych objawów i postaw występujących u pacjentów depresyjnych. Od czasu opublikowania pierwszej wersji BDI kwestionariusz stał się najpopularniejszym narzędziem służącym do samoopisu nasilenia objawów zespołu depresyjnego. W Polsce spotykany jest pod nazwami Skali Depresji Becka, Inwentarza Depresji Becka, czy Kwestionariusza Depresji Becka. Stosowany był w badaniach nad zaburzeniami psychicznymi, ale także we wszelkich innych analizach schorzeń internistycznych, onkologicznych, urologicznych, ginekologicznych, neurologicznych, w których przedmiotem badania była ocena nastroju pacjenta. Kwestionariusz BDI wykorzystywany jest jako przesiewowe narzędzie diagnostyczne do pomiaru natężenia objawów depresji, monitorowania dynamiki zmian w nasileniu poszczególnych objawów depresji, jako ocena skuteczności farmakoterapii i psychoterapii w leczeniu depresji oraz jako dodatkowa, oprócz oceny klinicznej, subiektywna miara normotymii ${ }^{18}$.

Kwestionariusz ten składa się z 21 pozycji, z przypisanymi im skalami odpowiedzi od zera (objaw nie występuje) do 3 punktów (największe nasilenie objawu). W tej wersji kwestionariusza przyjęto, że wyniki od 0 do 8 punktów oznaczają brak objawów depresji, od 9 do 18 - umiarkowane nasilenie, a powyżej 18 - znaczne nasilenie depresji.

${ }^{16}$ Psychiatria, s. 343-415.

${ }_{17}$ J. Morrison, DSM-5 bez tajemnic.

${ }_{18}$ B. Zawadzki, A. Popiel, E. Pragłowska, Charakterystyka psychometryczna polskiej adaptacji Kwestionariusza DepresjiBDI Aarona T. Becka, Psychologia-Etologia-Genetyka, 2009, 19. 


\section{Zaburzenia depresyjne wśród badanych studentów}

W teście Becka 23,5\% osób badanych uzyskało wyniki świadczące o łagodnym przebiegu depresji, a 6,5\% badanych wskazuje na objawy depresji umiarkowanej i głębokiej. Należy zauważyć, że wyniki uzyskane za pomocą testu Becka potwierdzają te, które pochodzą z raportu WHO (2017) odnośnie skali depresji na świecie, z którego wynika, że w Polsce 5,1\% osób cierpi na depresję, co stanowi 1,8 mln obywateli.

\section{Analiza wyników badań testem Becka - poszczególne Podskale}

Stan smutku może towarzyszyć w różnych okolicznościach i sytuacjach życiowych, a okres studiowania związany jest z sytuacją odnalezienia się w nowych rolach społecznych; często w odosobnieniu należy zintegrować swoje zasoby z oczekiwaniami społecznymi. Jest to czas, gdzie poczucie smutku czy przygnębienia może być spowodowane nowymi obowiązkami, czy koniecznością samowystarczalności i posiadania planów na przyszłość. Jest to też czas doświadczania intensywnych relacji społecznych i intymnych, może wiązać się z odrzuceniem bądź samotnością.

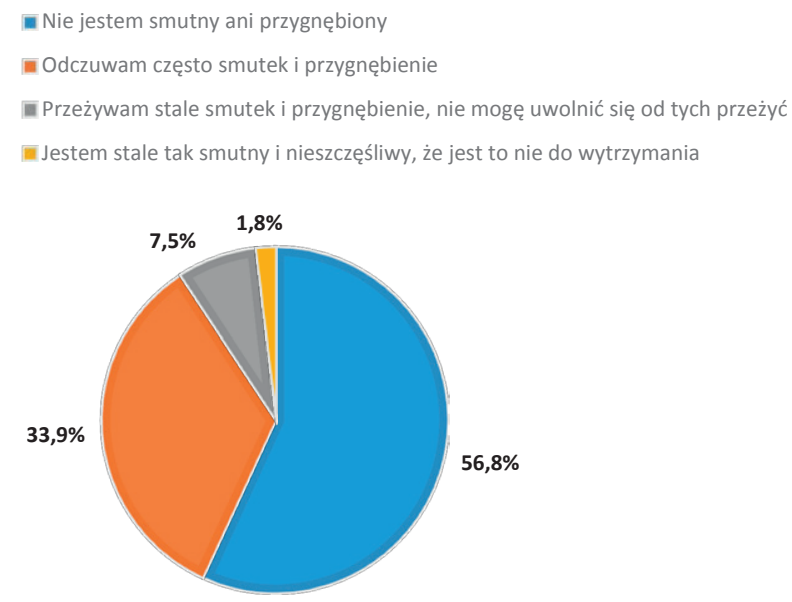

Ryc. 1. Odczuwanie smutku przez osoby badane - badanie przeprowadzone za pomocą testu Becka $(\mathrm{N}=4425)$ 
Ponad połowa badanych $(56,8 \%)$ nie doświadczała uczucia smutku i przygnębienia $\mathrm{w}$ momencie wykonywania testu. Jednak co trzecia osoba badana $(33,9 \%)$ wskazała na często doświadczany stan przygnębienia i smutku.

Żyjemy w czasach permanentnej zmiany, niepewności zatrudnienia, poczuciu braku kompetencji, w czasach, kiedy coraz częściej dochodzi do zmian związanych z zapotrzebowaniem pracowników. Okres podjęcia edukacji na wyższych szczeblach związany jest planowaniem kariery zawodowej i podjęciem zobowiązań, które w przyszłości będą miały swoje konsekwencje ${ }^{19}$. Perspektywa temporalna ulega zmianie, poszerza się wizja swojej przyszłości przy uwzględnieniu własnych zasobów, stąd ryzyko martwienia się o swoją przyszłość, które jest jednak wpisane w zadania rozwojowe młodego człowieka.

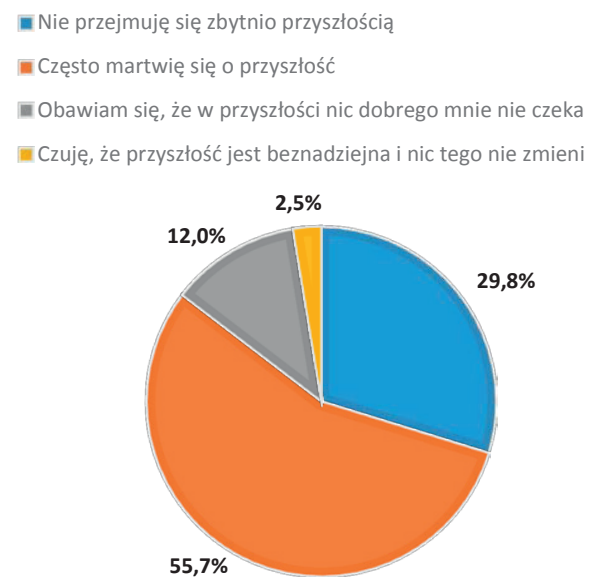

Ryc. 2. Perspektywa przyszłości w odczuciu badanych osób - badanie przeprowadzone za pomocą testu Becka $(\mathrm{N}=4413)$

Tylko jedna trzecia osób badanych $(29,8 \%)$ nie przejmuje się zbytnio swoją przyszłością, natomiast ponad połowa $(55,7 \%)$ często martwi się o swoją przyszłość, a 12,0\% badanych obawia się, że w przyszłości nie czeka ich nic dobrego.

Integralną częścią myślenia o sobie jako człowieku zdolnym realizować zadania rozwojowe i plany na przyszłość, czy myślenia o sobie jako człowieku kompetentnym, spełniających oczekiwania społeczne jest zdolność do podejmowania zobowiązań i konsekwentne rozliczanie się z nich.

${ }_{19}$ A. Cybal-Michalska, Młodzież akademicka a kariera zawodowa, Kraków 2018. 


\begin{abstract}
ॠ Sądzę, że nie popełniam większych zaniedbań
=Sądzę, że czynię więcej zaniedbań niż inni

- Kiedy spoglądam na to co robiłem, widzę mnóstwo błędów i zaniedbań

En Jestem zupełnie niewydolny i wszystko robię źle
\end{abstract}

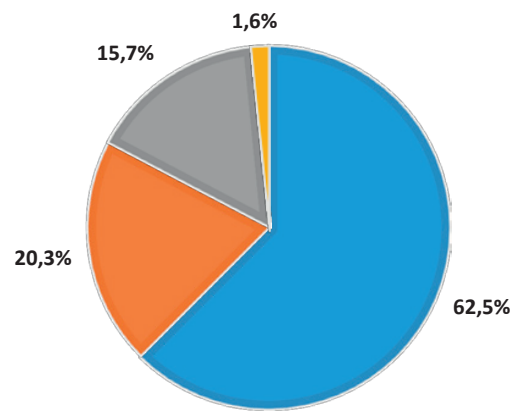

Ryc. 3. Zaniedbywania w poczuciu badanych osób - badanie przeprowadzone za pomocą testu Becka $(\mathrm{N}=4414)$

Znaczna część badanych (62,5\%) osób ma poczucie, że wywiązuje się $\mathrm{z}$ powierzonych zadań $\mathrm{w}$ stopniu zadowalającym, nie popełniając większych zaniedbań.

Na dobrostan psychiczny składa się badawcza i emocjonalna ocena swojego życia. Pojęcie to obejmuje doświadczanie przez człowieka pozytywnych emocji, niski poziom szkodliwych nastrojów, a także wysoki poziom zadowo-

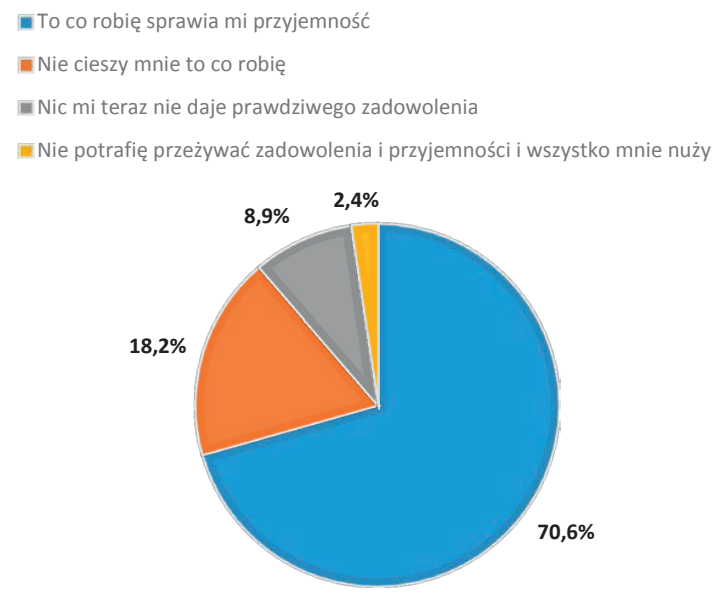

Ryc. 4. Odczuwana przyjemność w poczuciu badanych osób - badanie przeprowadzone za pomocą testu Becka $(\mathrm{N}=4424)$ 
lenia z życia, który zakłada także dobre relacje z innymi ludźmi ${ }^{20} . \mathrm{Z}$ pojęciem dobrostanu psychicznego wiąże się wykonywanie czynności, które w subiektywnym odczuciu dają poczucie zadowolenia i radości, gdzie człowiek czerpie przyjemność. Brak odczuwania przyjemności związany jest z jednym z obszarów depresji.

Zdecydowana większość badanych osób (70,6\%) odczuwa przyjemność z wykonywanych czynności życia codziennego lub większych zobowiązań, jakie podjęli w toku wyznaczania sobie celów.

Nienormatywne poczucie winy ma związek z doświadczanym obniżonym nastrojem i nie jest związane z dokonanymi czynami, o których zdaje sobie sprawę i się je pamięta, jest istotnym elementem $w$ diagnostyce depresji.
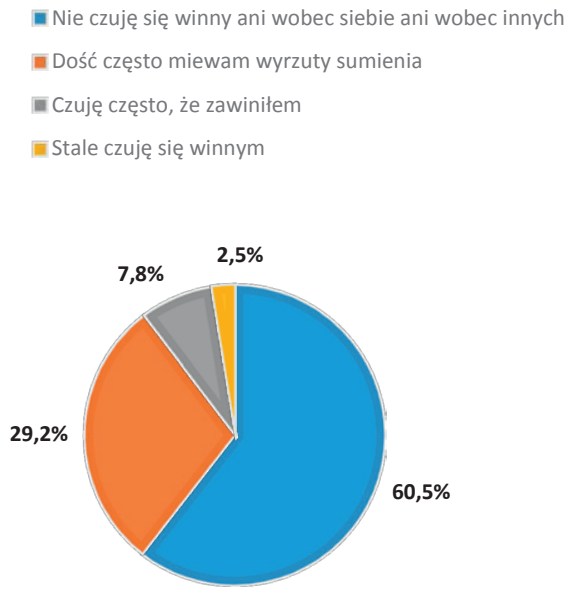

Ryc. 5. Poczucie winy badanych osób - badanie przeprowadzone za pomocą testu Becka $(\mathrm{N}=4419)$

Co trzecia osoba dość często $(29,2 \%)$ miewa poczucie winy, 7,8\% osób badanych często czuje, że zawiniła, a 2,5\% stale czuje się winna.

Kary i nagrody są $\mathrm{w}$ naszym społeczeństwie normatywnym systemem wychowawczym, który zakłada wzmocnienie pożądanych zachowań poprzez nagradzanie i wygaszanie, niepożądanych - poprzez karanie, które również może być związane z odebraniem nagrody. Jesteśmy w tym systemie wychowywani, edukowani i w nim też uczestniczymy, podejmując pracę zarobkową. Oczekiwanie na karę czy nagrodę po prezentowanym zachowaniu lub dokonaniu jakiegoś czynu jest normalnym zjawiskiem psychologicznym.

${ }^{20}$ E. Diener, R.E. Lucas, S. Oishi, Dobrostan psychiczny. Nauka o szczęściu i zadowoleniu z życia, [w:] Psychologia pozytywna. Nauka o szczęściu, zdrowiu, sile i cnotach człowieka, red. J. Czapiński, Warszawa 2004, s. 35-50. 
Jednak nieuzasadnione poczucie, że zasługuje się na karę, że wszystkie zachowania, które mogą należeć do normatywnych są poddawane ocenie i ktoś może zastosować karę wobec nas jest zjawiskiem zasługującym na bliższe przyjrzenie się, gdyż wynika z zaburzeń różnego typu. Jest jednym ze skła-

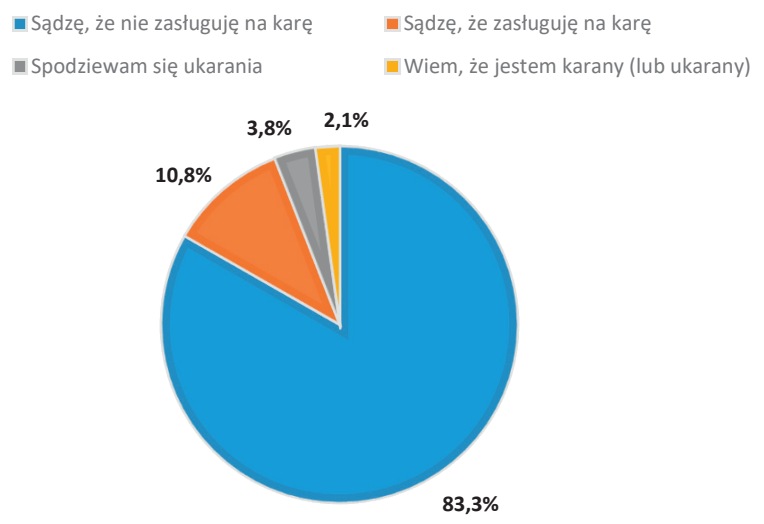

dowych zaburzenia depresyjnego.

Ryc. 6. Kara w poczuciu badanych osób - badanie przeprowadzone za pomocą testu Becka $(\mathrm{N}=4402)$

Zdecydowana większość badanych (83,3\%) nie ma poczucia, że zasługuje na karę, jednak co 10 . osoba $(10,8 \%)$ uważa, że jej dotychczasowe zachowanie wskazuje, że mogłaby być ukarana.

Bycie zadowolonym $\mathrm{z}$ siebie jest często wynikiem spełnienia oczekiwań społecznych i realizowania własnych standardów wyznaczonych sobie w kontekście swojej osoby.

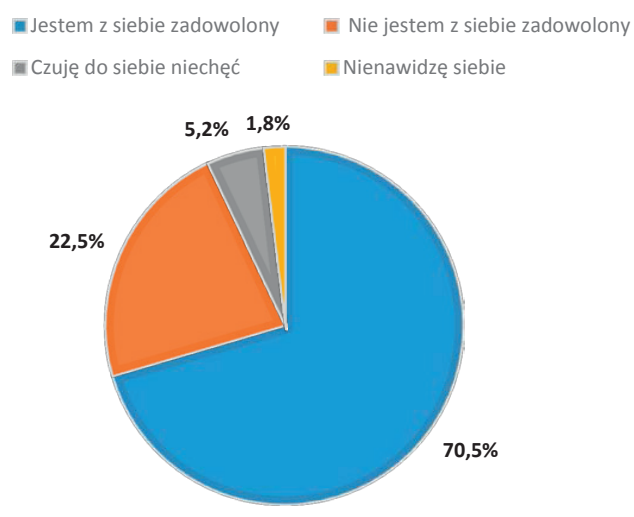

Ryc. 7. Zadowolenie w poczuciu badanych osób - badanie przeprowadzone za pomocą testu Becka $(\mathrm{N}=4420)$ 
Znaczną część badanych (70,5\%) stanowią osoby, które uznają, że są zadowolone $\mathrm{z}$ siebie.

Człowiek jest istotą społeczną i porównywanie się z innymi pozwala na dokonanie własnej oceny i wyznaczenia standardów osobistych. Często dokonujemy oceny „w górę”; porównujemy się z osobami, które są od nas lepsze, w naszym przekonaniu, by móc wyznaczać sobie kolejne cele. Jednak nieustanne poczucie bycia gorszym od innych wpływa demotywująco na nasze zachowania.
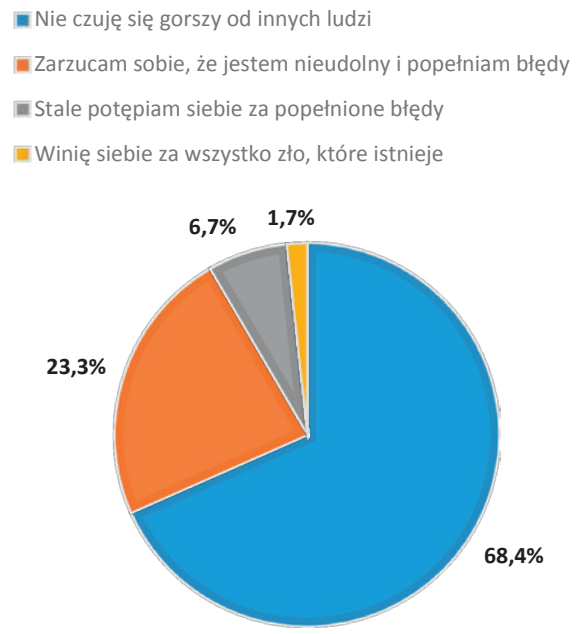

Ryc. 8. Porównywanie się z innymi w poczuciu badanych osób - badanie przeprowadzone za pomocą testu Becka $(\mathrm{N}=4423)$

Co czwarta osoba $(23,3 \%)$ zarzuca sobie, że jest nieudolna i popełnia błędy. Ponad połowa $(68,4 \%)$ uznała jednak, że nie czują się gorsi od innych.

Chęć życia wynika z naturalnej potrzeby człowieka do rozwoju. Kryzys suicydalny świadczący o dezintegracji osobowości i oddzieleniu zdrowych części psychiki od chorych, związany z brakiem dostrzegania jakichkolwiek swoich zasobów, nie zawsze związany jest z chęcią odebrania sobie życia, ale również z brakiem chęci do życia, co nie zawsze jest jednoznaczne. Można nie chcieć popełnić samobójstwa, ale można nie chcieć dalej żyć tak, jak się żyje ${ }^{21}$. Jest to najtrudniejszy i najgorszy w odczuciu kryzys, jaki może doświadczać człowiek. Jednak brak myśli samobójczych nie wyklucza depresji.

${ }^{21}$ E. Karmolińska, Dysfunkcjonalność rodziny jako przejaw kryzysu suicydalnego, Pampaedia 2007/2008, 4-5. 


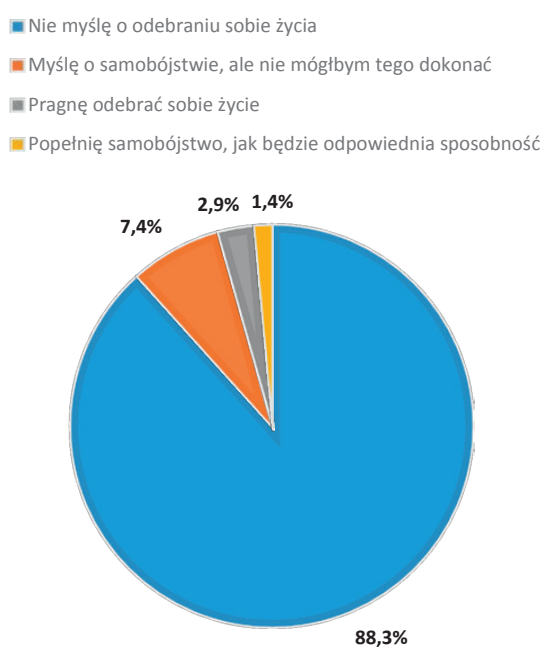

Ryc. 9. Samobójstwo w poczuciu badanych osób - badanie przeprowadzone za pomocą testu Becka $(\mathrm{N}=4402)$

Zdecydowana większość (88,3\%) badanych osób nie myśli o odebraniu sobie życia. Jednak $7,4 \%$ ma skłonności do upatrywania rozwiązania swojej sytuacji życiowej w możliwości odebrania sobie życia, jednak nie byłaby w stanie tego dokonać.

Płacz jest naturalną reakcją organizmu człowieka na smutek, niepokój, a nawet złość. W praktycznie każdej jednostce chorobowej to, co jest traktowane jako patologia, jeżeli występuje nadmiernie, w pewnym stopniu jest też normatywne, jeżeli występuje sporadycznie.

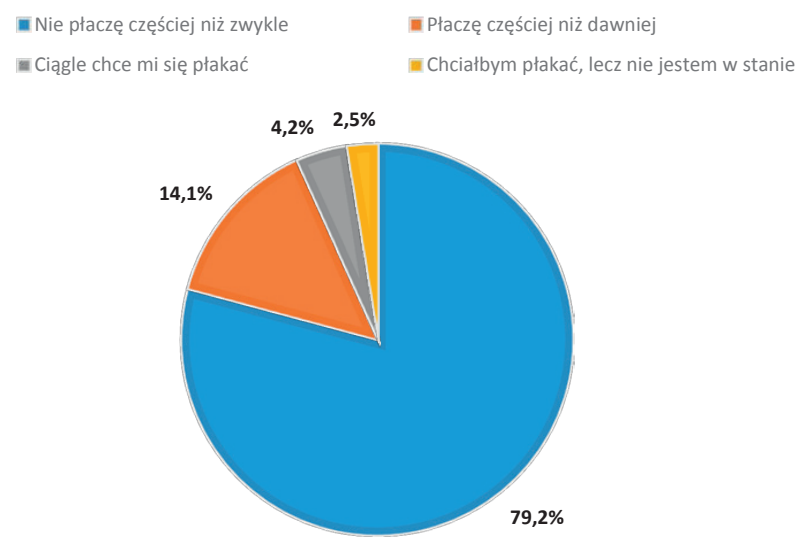

Ryc. 10. Płacz w poczuciu badanych osób - badanie przeprowadzone za pomocą testu Becka $(\mathrm{N}=4402)$ 
Zdecydowana większość osób (79,2\%) nie płacze częściej niż zwykle.

Poczucie podenerwowania i nieradzenie sobie $z$ normatywnymi sytuacjami stresowymi życia codziennego jest wynikiem skumulowania napięcia, które powstało w sytuacji stresowej lub traumatycznej i nie zostało w odpowiedni sposób zintegrowane. Występuje w ciele człowieka w tak zwanej pętli energetycznej i nie może dojść do rozładowania. Wówczas najdrobniejsza sytuacja, która jest niezgodna z oczekiwaniami jednostki, może zostać odebrana jako zagrażająca i następuje wybuch lub autoagresja. Żyjemy jednak w czasach, gdzie doświadczamy nadmiaru bodźców, jesteśmy wystawieni na sytuacje zagrożenia wynikające $\mathrm{z}$ martwienia się o przyszłość, w poczuciu braku sprawstwa, co może skutkować większym niż normatywnie oczekiwanym stanem podenerwowania przeciętnego człowieka ${ }^{22}$.

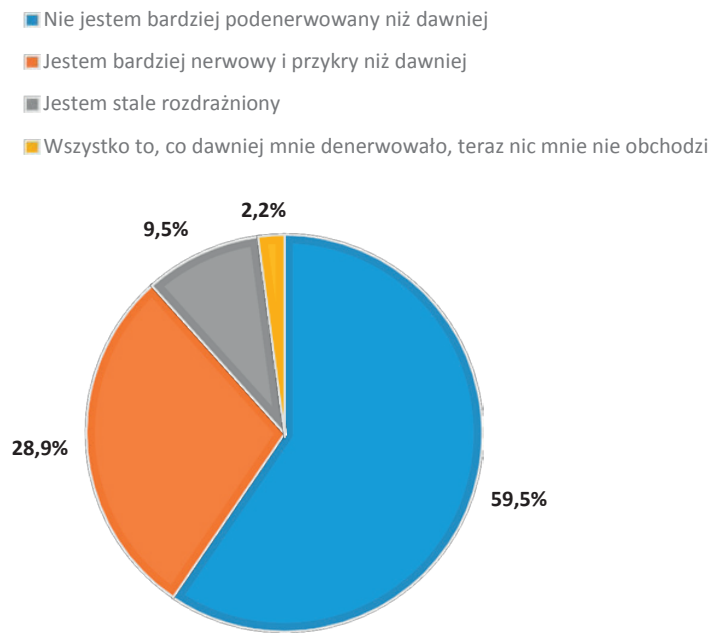

Ryc. 11. Nerwowość w poczuciu badanych osób - badanie przeprowadzone za pomocą testu Becka $(\mathrm{N}=4403)$

Co czwarty badany jest bardziej nerwowy niż dawnej (28,98\%) lub stale rozdrażniony (9,5\%), co wynikać może z nadmiaru obowiązku, szybkiego tempa życia, coraz częściej zwiększanych oczekiwań względem samych siebie.

Zainteresowanie innymi osobami jest również zależne od naszego postrzegania siebie i świata, w którym żyjemy. Czy mamy raczej tendencje do uznania innych i świata jako dobrych, przyjaznych czy zagrażających i wrogich. Inne osoby dostarczają nam informacji zwrotnych o nas samych, kiedyjesteśmy nimi zainteresowani, mamy ochotę pozyskiwać informacje od nich, czerpać z ich zasobów, ale też ich obdarowywać, czując się potrzebni.

${ }^{22}$ D. Berceli, Zaufaj ciału, Koszalin 2011. 


\section{- Ludzie interesują mnie jak dawniej \\ — Interesuję się ludźmi mniej niż dawniej \\ = Utraciłem większość zainteresowania innymi ludźmi \\ [i= Utraciłem wszelkie zainteresowanie innymi ludźmi}

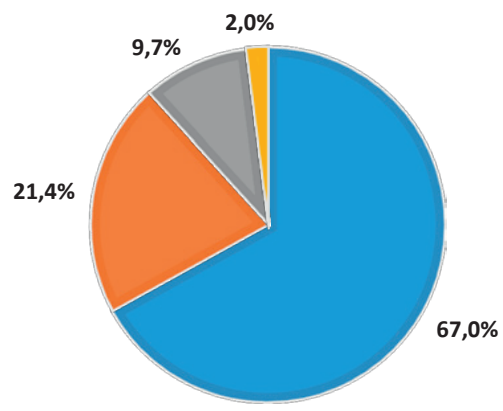

Ryc. 12. Zainteresowanie innymi w poczuciu badanych osób - badanie przeprowadzone za pomocą testu Becka $(\mathrm{N}=4400)$

Ponad połowa badanych $(67,0 \%)$ uznała, że inni ludzie ich interesują tak samo jak dotychczas. Natomiast, prawie co 4 . badany $(21,4 \%)$ uznał, że w porównaniu z okresem ubiegłym mniej się interesuje innymi osobami.

Prawidłowy rozwój psychospołeczny związany jest z umiejętnością podejmowania różnego rodzaju decyzji, które wiążą się również z ponoszeniem odpowiedzialności. Okres studiowania jest tym momentem w życiu człowieka, w którym niejednokrotnie musi podejmować decyzje związane z jego przyszłością w obszarach, w których do tej pory decyzje podejmowali

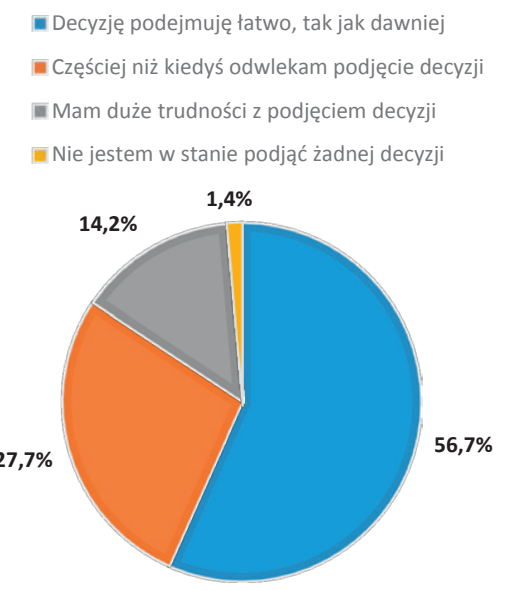

Ryc. 13. Podejmowanie decyzji w poczuciu badanych osób - badanie przeprowadzone za pomocą testu Becka $(\mathrm{N}=4403)$ 
rodzice lub opiekunowie. Poziom decyzyjności wzrasta z wiekiem i posiadanymi kompetencjami. Studiowanie to również okres moratorium psychospołecznego, które pozwala na dłuższe przyjrzenie się sobie i swoim celom życiowym, co może skłonić do odkładania pewnych decyzji w czasie ${ }^{23}$.

Połowa badanych $(56,7 \%)$ uznała, że podejmuje decyzje tak samo łatwo jak kiedyś, natomiast co czwarty badany $(27,7 \%)$ uznał, że obecnie odwleka podjęcie decyzji częściej niż kiedyś.

Wygląd zewnętrzny ma duże znaczenie w okresie powiększania grona znajomych, podejmowania aktywności zawodowej i edukacyjnej. Zaangażowanie i dbałość o wygląd może świadczyć o chęci życia, podobania się, uzyskania aprobaty i uznania ${ }^{24}$. Brak takich zachowań może być dowodem na utratę woli życia i zainteresowania nim. Okres studiowania to czas pozyskiwania nowych znajomych, otaczania się innymi niż dotychczas wpływami społecznymi grupy oraz czas zmian biologicznych, które mogą korzystnie lub niekorzystnie wpływać na atrakcyjność fizyczną i psychiczną.

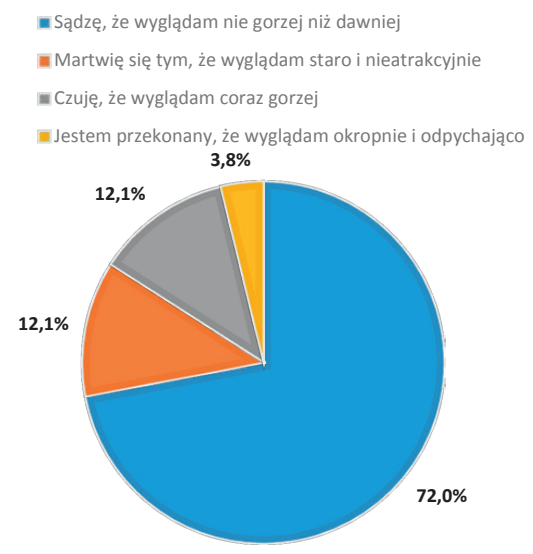

Ryc. 14. Wygląd zewnętrzny w poczuciu badanych osób - badanie przeprowadzone za pomocą testu Becka $(\mathrm{N}=4392)$

Zdecydowana większość (72,0\%) uznaje, że nie wygląda gorzej niż dawniej, a mimo to $12,0 \%$ badanych martwi się, że nie wygląda atrakcyjnie.

Praca jest najważniejszą aktywnością dorosłego człowieka, tak samo jak zabawa dla dziecka. Umożliwia rozwój poznawczy i społeczny, tworzy pewnego rodzaju ramy, w obszarze których człowiek funkcjonuje. Jeżeli praca jest wykonywana z zaangażowaniem, to nie tylko świadczy o odpowiednim doborze obowiązków do predyspozycji jednostki, ale również wskazuje na chęć życia i podejmowania różnych inicjatyw.

${ }^{23}$ E.H. Erikson, Dopetniony cykl życia, Poznań 2002.

24 Z. Melosik, Tożsamość, ciało i wtadza w kulturze instant, Kraków 2010. 

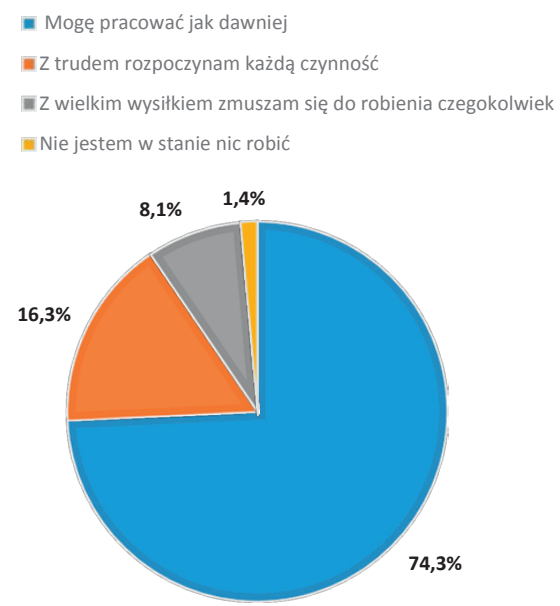

Ryc. 15. Praca w poczuciu badanych osób - badanie przeprowadzone za pomocą testu Becka $(\mathrm{N}=4392)$

74,3\% osób badanych uznało, że może w dalszym ciągu wykonywać swoją pracę, w takim samym zakresie jak dawniej. 16,3\% badanych z trudem rozpoczyna każdą czynność.

Jednym ze wskaźników dobrego samopoczucia jest odpowiedni sen, który trwa określony czas, po którym człowiek czuje się wypoczęty i gotowy do podejmowania dalszych czynności dnia codziennego oraz realizacji swoich obowiązków. Zaburzony sen jest objawem wielu chorób, w tym doświadczanego stresu czy depresji.

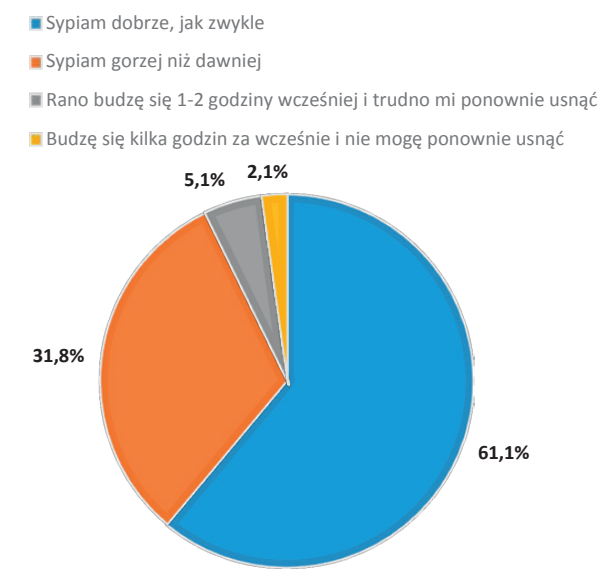

Ryc. 16. Sen w poczuciu badanych osób - badanie przeprowadzone za pomocą testu Becka $(\mathrm{N}=4398)$ 
Niewiele ponad połowa osób badanych $(61,1 \%)$ sypia dobrze, tak samo jak dotychczas, co trzecia osoba badana $(31,8 \%)$ sypia gorzej niż do tej pory, co jednak może być związane ze zmianą miejsca zamieszkania, nowymi obowiązkami, jakie podejmuje się podczas studiów.

Poczucie męczliwości jest wysoce subiektywne, jednak stany depresyjne, mimo że nie zawsze są odczuwane przez osobę je doświadczającą, stanowią męczliwość należącą do tych objawów, które pacjenci depresyjni często zgłaszają.

= Nie męczę się bardziej niż dawniej

= Męczę się wszystkim co robię

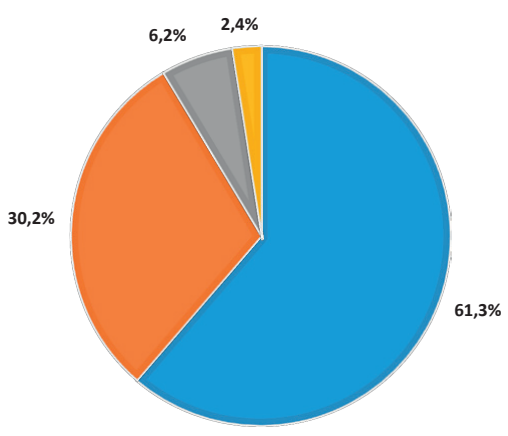

= Męczę się znacznie łatwiej niż poprzednio

Inestem zbyt zmęczony aby cokolwiek robić

Ryc. 17. Męczliwość w poczuciu badanych osób - badanie przeprowadzone za pomocą testu Becka $(\mathrm{N}=4400)$

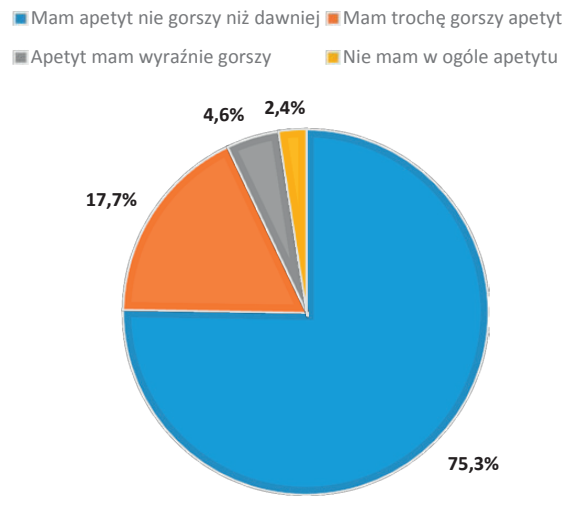

Ryc. 18. Apetyt w poczuciu badanych osób - badanie przeprowadzone za pomocą testu Becka $(\mathrm{N}=4405)$

Ponad połowa badanych $(61,3 \%)$ osób nie męczy się bardziej niż dotychczas, co trzecia osoba badana $(30,2 \%)$ odczuwa większą męczliwość niż 
wcześniej, co może również być związane ze zmianami, jakie zaszły w życiu młodego człowieka, w okresie przejścia z wczesnej adolescencji do życia dorosłego.

Obszar związany z przyjmowaniem pożywienia jest jednym z tych, które łączone są często z przyjemnością. Posiadanie odpowiedniego apetytu, nie nadmiernego, niezbyt małego świadczy, że organizm funkcjonuje prawidłowo i przekazuje informacje o zapotrzebowaniu na niezbędne do życia substancje odżywcze. Jeżeli apetyt jest obniżony, możemy wnioskować o pojawiających się zaburzeniach.

Zdecydowana większość osób badanych $(75,2 \%)$ ma dobry apetyt - taki sam jak dawniej.

Z brakiem apetytu związana jest utrata wagi. Jednak należy mieć na uwadze, że choroby związane $\mathrm{z}$ brakiem łaknienia i utratą wagi należą do objawów maskujących depresję, ale nie zawsze muszą z nią być powiązane.

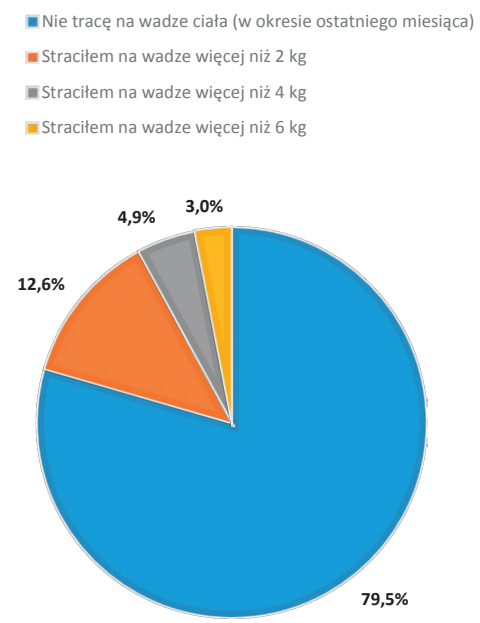

Ryc. 19. Waga ciała osób badanych - badanie przeprowadzone za pomocą testu Becka $(\mathrm{N}=4401)$

Zdecydowana większość osób badanych nie straciła na wadze w okresie ostatniego miesiąca. $12,6 \%$ badanych to osoby, które uznały, że straciły $2 \mathrm{~kg}$, a 4,9\% badanych straciła $4 \mathrm{~kg}$ wagi w okresie ostatniego miesiąca. Może być to efekt kultu szczupłej sylwetki, propagowania zdrowego stylu życia, którego konsekwencją może być spadek wagi.

Zdrowie jest tym obszarem, które zazwyczaj zaczyna być w polu zainteresowania w momencie, kiedy odczuwalny jest ewidentny spadek kondycji, 
widoczne są objawy chorobowe, gdy człowiek, często wraz z wiekiem, traci zdrowie. Jednak w wieku wczesnej dorosłości martwienie się o swoje zdrowie może być wskaźnikiem do dalszej obserwacji w kontekście pogarszania się stanu zdrowia, zarówno psychicznego jak i fizycznego.

= Nie martwię się o swoje zdrowie bardziej niż zawsze

= Martwię się swoimi dolegliwościami, mam rozstrój żołądka, zaparcia, bóle

= Stan mego zdrowia bardzo mnie martwi, często o tym myślę

Eardzo martwię się o swoje zdrowie, nie mogę o niczym innym myśleć

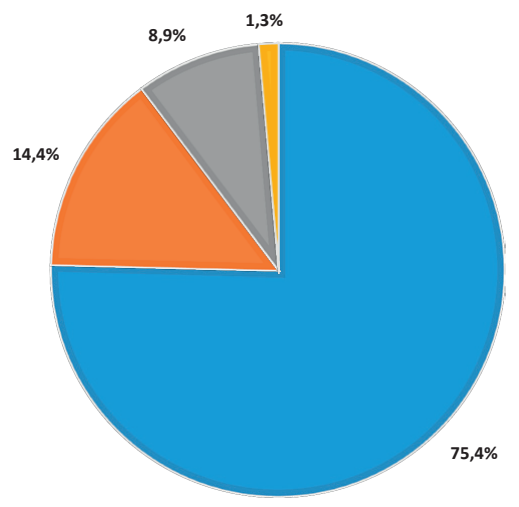

Ryc. 20. Zdrowie w poczuciu badanych osób - badanie przeprowadzone za pomocą testu Becka $(\mathrm{N}=4401)$

- Moje zainteresowania seksualne nie uległy zmianom

- Jestem mniej zainteresowany sprawami płci (seksu)

= Problemy płciowe wyraźnie mnie nie interesują

In Utraciłem wszelkie zainteresowanie sprawami seksualnymi

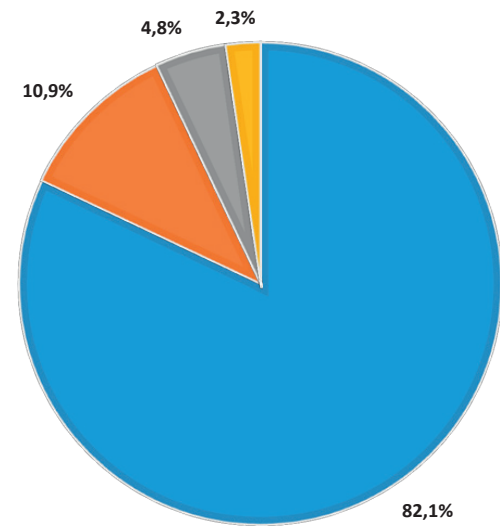

Ryc. 21. Zainteresowania seksualne osób badanych - badanie przeprowadzone za pomocą testu Becka $(\mathrm{N}=4252)$ 
Podobnie jak we wcześniejszych podtestach, większość osób badanych $(75,4 \%)$ nie martwi się o swoje zdrowie bardziej niż zwykle.

Życie seksualne młodych dorosłych powinno być traktowane w sposób szczególny, gdyż stwarza możliwość realizacji zadań rozwojowych, jest źródłem przyjemności, może być dowodem bliskości i sposobnością do rozładowania popędów agresywnych. Pod względem działania zegara biologicznego, jak i społecznego, jednostki w tym wieku są gotowe do prokreacji, co oznacza, że jest to okres wzmożonej reaktywności i pobudzenia oraz realizowania w określonych warunkach wielu przyjemności. Brak zainteresowania sferą życia seksualnego w tym okresie rozwojowym świadczy o możliwości pojawienia się trudności zdrowotnych.

Zdecydowana większość badanych $(82,1 \%)$ uznała, że ich zainteresowania seksualne nie uległy zmianom, natomiast 10 osób na 100 uznało, że jest mniej zainteresowanych sprawami związanymi z seksem.

\section{Zaburzenia depresyjne a płeć}

Wśród osób, które uzyskały wyniki świadczące o zaburzeniach depresyjnych 73,3\% stanowiły kobiety, a 26,7\% mężczyźni, co jest zgodne z rozkładem normalnym w populacji ogólnej, gdzie kobiety są bardziej narażone na depresję niż mężczyźni. W badaniach E. Mojs i współpracowników ${ }^{25}$ wśród kobiet biorących udział w badaniu 30,2\% osób ma zaburzenia depresyjne, a wśród mężczyzn 21,8\% osób wykazuje występowanie takich zaburzeń.

Istnieje zależność pomiędzy płcią a uzyskanymi wynikami w skali depresji: chi-kwadrat $=32,53 ; \mathrm{p}=0,00$, przy czym siła zależności jest niska: $\varphi$ Yula $=0,0862$. Wśród osób, które uzyskały wyniki świadczące o głębokiej lub umiarkowanej depresji $73,3 \%$ stanowią kobiety, a 26,7\% to mężczyźni. Wśród kobiet 32,5\% wykazuje zaburzenia depresyjne, natomiast wśród mężczyzn 24,3\%. Istnieje zależność między płcią a uzyskanymi wynikami świadczącymi o zaburzeniu depresyjnym: chi-kwadrat $=30,29 ; p=0,00$, natomiast siła zależności jest słaba: $\varphi$ Yula =0,083.

\section{Podsumowanie}

Z powyższych danych wynika, że zdecydowana większość osób nie wykazuje zaburzeń depresyjnych. Jednakże, uzyskane dane są niepokojące, gdyż potwierdzają tendencję wzrostową w wykrywaniu zaburzeń depresyjnych.

${ }^{25}$ E. Mojs i in., Właściwości psychometryczne polskiej wersji skróconej Skali Depresji Kutchera, s. $135-144$. 
Zgodnie z prognozami WHO (2017), liczba zachorowań na depresję będzie cały czas wzrastać. $Z$ badań naukowych ${ }^{26}$ wynika, że zapadalność na depresję zwiększa się wśród społeczeństwa krajów rozwiniętych. Brakuje jednak badań przesiewowych, a pomimo tego szacuje się, że jedynie u około połowy pacjentów z objawami ciężkiej depresji rozpoznaje się depresję, z czego tylko $50 \% \mathrm{z}$ nich otrzymuje odpowiednie leczenie farmakologiczne. Nieleczona depresja związana jest ze zwiększonym ryzykiem samobójstw i zgonów, a także wystąpieniem chorób somatycznych i odwrotnie - choroby somatyczne sprzyjają rozwinięciu depresji ${ }^{27}$. Szacuje się (WHO, 2017), że do roku 2020 depresja będzie na drugim miejscu zachorowań, a do 2030 - na pierwszym.

Ponadto, wśród badanej populacji zauważa się, że to studentki są bardziej narażone na zaburzenia depresyjne niż mężczyźni.

Najsłabsze wyniki studentki i studenci uzyskali w podtestach związanych z:

- odczuwanym smutkiem: co trzecia osoba badana (33,9\%) wskazała na często doświadczany stan przygnębienia i smutku, a 7,5\% jest stale przygnębionych tak, że uczucie smutku jest nie do zniesienia;

- zamartwianiem się o własną przyszłość: ponad połowa (55,7\%) często martwi się o swoją przyszłość, a 12,0\% badanych obawia się, że w przyszłości nie czeka ich nic dobrego;

- poczuciem winy: co trzecia osoba dość często $(29,2 \%)$ miewa poczucie winy, $7,8 \%$ osób badanych często czuje, że zawiniła, a 2,5\% stale czuje się winna;

- uczuciem nerwowości: co czwarta badana osoba jest bardziej nerwowa niż dawnej $(28,98 \%)$ lub stale rozdrażniona $(9,5 \%)$;

- podejmowaniem decyzji: co czwarta badana osoba (27,7\%) uznała, że obecnie odwleka podjęcie decyzji częściej niż kiedyś;

- snem: co trzecia osoba badana (31,8\%) sypia gorzej niż do tej pory;

- poczuciem męczliwości: co trzecia osoba badana (30,2\%) odczuwa większą męczliwość niż wcześniej.

Powyższe kategorie, bardzo często związane w literaturze przedmiotu, przypisywane są dynamicznym zmianom zachodzącym w społeczeństwach postindustrialnych, w czasach globalizacji, ponowoczesnych zmian. Z. Bauman zauważa, że znajdujemy się w okresie tak zwanego bezkrólewia, czyli między czasem, kiedy mieliśmy pewniki, a czasem, gdy stare sposoby działania przestały funkcjonować, a jednocześnie nie wiemy co je zastąpi.

${ }^{26}$ G. Vilagut, C.G. Forero, G. Barbaglia, Screening for depression in the general popula-tion with the Center for Epidemiologic Studies Depression (CES-D): a systematic review with meta-analysis, PloS One, 2016, 11(5).

${ }^{27}$ A. Banaś, H. Wichowicz, M. Gałuszko, Wspótchorobowość somatyczna w zaburzeniach depresyjnych, Psychiatria w Praktyce Ogólnolekarskiej, 2005, 2(5), s. 69-73. 
Studenci znajdują się w takim momencie swojego życia, w którym zmuszeni są dokonywać wyborów, podejmować wiążące decyzje życiowe ${ }^{28}$. Mają oni świadomość, że od tych decyzji zależeć będzie ich przyszłe życie i jego jakość, a jednocześnie nie wiedzą, w jakim kierunku nastąpi dalszy rozwój w ujęciu makrospołecznym. Brak pewności siebie, brak stabilizacji, nadmiar obowiązków, przy jednoczesnym braku wsparcia biskich osób, może prowadzić do odczuwania przygnębienia, smutku i zachowań z zakresu objawów depresyjnych.

\section{BIBLIOGRAFIA}

Berceli D., Zaufaj ciatu, OBPzC, Koszalin 2011.

Banaś A., Wichowicz H., Gałuszko M., Wspótchorobowość somatyczna w zaburzeniach depresyjnych, Psychiatria w Praktyce Ogólnolekarskiej, 2005, 2(5).

Cybal-Michalska A., Młodzież akademicka a kariera zawodowa, Oficyna Wydawnicza Impuls, Kraków 2018.

Czapiński J., Polski generalny sondaż dobrostanu psychicznego: badanie panelowe 1991 i 1992: struktura danych i podstawowe statystyki, Polskie Towarzystwo Psychologiczne, Pracownia Wydawnicza, Warszawa 1993.

Dąbrowski K., Zdrowie psychiczne, Państwowe Wydawnictwo Naukowe, Warszawa 1985.

Diener E., Lucas R.E., Oishi S., Dobrostan psychiczny. Nauka o szczęściu i zadowoleniu z życia, [w:] Psychologia pozytywna. Nauka o szczęściu, zdrowiu, sile i cnotach człowieka, red. J. Czapiński, Wydawnictwo Naukowe PWN, Warszawa 2004.

Erikson E.H., Dopetniony cykl życia, Dom Wydawniczy Rebis, Poznań 2002.

Godlewska B.R., Genetyka i psychiatria w praktyce lekarskiej, Psychiatria w Praktyce Ogólnolekarskiej, 2007, 7(2).

Godlewski S., Czerski P., Badania genetyczno-molekularne metoda analizy sprzężeń dotyczace schizofrenii. Przegląd piśmiennictwa, Nowiny Lekarskie, 2000, 69.

Hasler G., Patofizjologia depresji: czy mamy jakieś solidne dowody naukowe interesujące dla klinicystów? Postępy Psychiatrii i Neurologii, 2011, 20.

James W., The principles of psychology, Holt, New York 1890.

Jonata B., Załuska M., Poziom kortyzolu, dehydroepiandrosteronu i jego siarczanu (DHEA i DHEA-S) w surowicy krwi a obraz lipidogramu i reakcja na leczenie u kobiet $z$ depresja, Psychiatria Polska, 2011, XLV, 6.

Karmolińska E., Dysfunkcjonalność rodziny jako przejaw kryzysu suicydalnego, Pampaedia, 2007/2008, 4-5.

Markowicz-Narękiewicz A.E., Związek pomiędzy wydzielaniem neuroprzekaźników a powstaniem chorób psychicznych - na szczegółowo omawianym przykładzie depresji, [w:] Neurokognitywistyka w patologii i zdrowiu, Pomorski Uniwersytet w Szczecinie, Szczecin 2015.

Melosik Z., Tożsamość, ciało i władza w kulturze instant, Oficyna Wydawnicza Impuls, Kraków 2010.

Mitjans M., Arias B., The genetics of depression: What information can new methodologic approaches provide? Actas Esp Psiquiatr., 2012, 40.

${ }^{28}$ Z. Bauman, https://elpais.com/cultura/2014/08/24/actualidad/1408896685_914050. html [data dostępu: 08.12.2019]. 
Mojs E., Bartkowska W., Kaczmarek Ł., Ziarko M., Bujacz A., Warchoł-Biedermann K., Wtaściwości psychometryczne polskiej wersji skróconej Skali Depresji Kutchera dla Młodzieży (Kutcher Adolescent Depression Scale) - pomiar depresji w grupie studentów, Psychiatria Polska, 2015, 49(1).

Morrison J., DSM-5 bez tajemnic. Praktyczny przewodnik dla klinicystów, Wydawnictwo Uniwersytetu Jagiellońskiego, Kraków 2016.

Psychiatria, red. J. Rybakowski, J. Wciórka, tom II, Wydawnictwo Medyczne Urban \& Partner, Wrocław 2011.

Rajewska-Rager A., Rybakowski J., Rola stresujacych wydarzeń życiowych w patogenezie depresji, Neuropsychiatria Neuropsychologia, 2008, 3.

Sadock B.J., Sadock V.A., Ruiz P., Kaplan E Sadock's Synopsis of Psychiatry Behavioral Sciences/Clinical Psychiatry, wyd. 11, Wolters Kluwer, Philadelphia 2015.

Shannon K.E., Beauchaine T.P., Brenner S.L., Neuhaus E., Gatzke-Kopp L., Familial and temperamental predictors of resilience in children at risk for conduct disorder and depression, Development and Psychopathology, 2007, 19.

Szpera A., Badania genów kandydujących zwiąanych z układem serotoninergicznym $i$ dopaminergicznym w zespole obsesyjno-kompulsywnym, Nowiny Lekarskie, 2008, 77.

Zawadzki B., Popiel A., Pragłowska E., Charakterystyka psychometryczna polskiej adaptacji Kwestionariusza Depresji BDI Aarona T. Becka, Psychologia-Etologia-Genetyka, 2009, 19.

Vilagut G., Forero C.G., Barbaglia G., Screening for depression in the general population with the Center for Epidemiologic Studies Depression (CES-D): a systematic review with meta-analysis, PLoS One, 2016, 11(5).

\section{Strony internetowe}

https://www.who.int/mental_health/management/depression/en/ [data dostępu: 02.11.2019].

http://twarzedepresji.pl/o-depresji-swiecie/ [data dostępu: 02.11.2019].

https:/ / stat.gov.pl > gfx > portalinformacyjny > defaultaktualnosci > region [data dostępu: 31.10.2019].

Bauman Z., https://elpais.com/cultura/2014/08/24/actualidad/1408896685_914050.html [data dostępu: 08.12.2019]. 